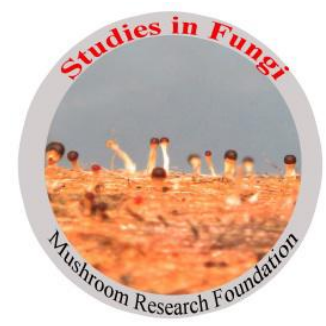

\title{
Article
}

Doi 10.5943/sif/1/1/4

\section{Copyright $\mathbb{C}$ Mushroom Research Foundation 2016}

\section{Diversity of arbuscular mycorrhizal fungi (Glomeromycota) in maritime sand dunes of Brazilian northeast}

\section{Jobim $\mathrm{K}^{1}$ and Goto $\mathrm{BT}^{2}$}

\author{
${ }^{1}$ Programa de Pós-Graduação em Sistemática e Evolução, Universidade Federal do Rio Grande do Norte, Natal, Rio \\ Grande do Norte 59072-970, khadija jobim@hotmail.com \\ ${ }^{2}$ Departamento de Botânica e Zoologia, Universidade Federal do Rio Grande do Norte, Natal, Rio Grande do Norte \\ 59072-970
}

Jobim K, Goto BT 2016 - Diversity of arbuscular mycorrhizal fungi (Glomeromycota) in maritime sand dunes of Brazilian northeast. Studies in Fungi 1(1), 43-55, Doi 10.5943/sif/1/1/4

\begin{abstract}
The symbiotic association between AMF and plants in coastal areas is a major strategy for the survival of native vegetation, due to the ability of external hyphae of fungi to absorb the scarce nutrients in substrates and to further the aggregation of soil particles promoting its stability. Despite its importance to the maintenance of coastal ecosystems, little is known about the dynamics of the AMF communities in tropical areas. The aim of this study was to evaluate the occurrence and diversity of AMF in maritime dunes from the Parque Ecológico Dunas de Genipabu, in Rio Grande do Norte (RN), Brazil. From August / 2010 to February / 2012, on four occasions in the rainy and dry seasons, rhizosphere soil samples from 48 plants were collected and 46 species of AMF were found, distributed among 10 families: Glomeraceae (12), Acaulosporaceae (7) Dentiscutataceae (7), Diversisporaceae (2), Gigasporaceae (5), Scutellosporaceae (4), Ambisporaceae (3), Racocetraceae (3), Intraornatosporaceae (2) and Sacculosporaceae (1). A higher richness and diversity were associated with dry season. The data obtained show that coastal areas are AMF diversity hotspots, with a high number of species associated with native vegetation.
\end{abstract}

Key words - mycorrhiza - Poales - symbiosis - taxonomy

\section{Introduction}

Arbuscular mycorrhizal fungi (AMF) comprises the Glomeromycota phylum which is organized in three classes, five orders, 15 families, 38 genera and approximately 280 species (Oehl et al 2011a, 2014, Goto et al 2012a, Błaszkowski et al 2014). These fungi establish obligate symbiotic association with more than $80 \%$ of representatives of land plants (Gianinazzi \& Gianinazzi-Pearson 1986), promoting growth and tolerance of the plant to biotic and abiotic stresses (Souza 2007), due to the ability of external hyphae of fungi to absorb the scarce nutrients from substrates (Smith \& Read 2008).

Symbiotic association between plants and AMF is essential for the establishment and survival of plants in ecosystems with extreme environmental conditions, such as the dune areas (Janos 1980). In this case, the native plants in dunes must constantly deal with various environmental stresses, such as transportation and instability of the substrate (Barbour 1992), distance from the water table (Ranwell 1959) and salinity (Wilson \& Sykes 1999). Reports have been made about the effective participation of AMF associated with plants destined to fixing 
mobile soils (Reeves et al 1979), especially about the benefits of the establishment of vegetation on saline soils (Allen \& Cunningham 1983, Levy et al 1983).

The importance of the AMF for the establishment and growth of plants inhabiting coastal dunes have been studied for temperate regions (Gerdemann \& Trappe 1974, Błaszkowski 1993, 1994), tropical (Beena et al 2000, 2001, Souza et al 2011, Silva et al 2012), subtropical (Błaszkowski 2004, Stürmer et al 2013), desert (McGee \& Trappe 2002, Błaszkowski \& Czerniawska 2008) and continental (Berch \& Trappe 1985). However, the studies on the Brazilian coast are limited, distributed only through the states of São Paulo (Trufem et al 1989, 1994, Trufem 1990, 1995), Santa Catarina (Stürmer \& Bellei 1994, Cordoba et al 2001, Stürmer et al 2013), Paraíba (Oliveira et al 2009, Souza et al 2011, Silva et al 2012) and Bahia (Santos et al 1995).

In the initial portion of the coastal zone of Rio Grande do Norte there are mobile or semifixed dunes where the vegetation is absent or having very sparse coverage, making this mobile soil vulnerable to the action of the winds. More into the continent, the vegetation thickens up over the dunes, forming the fixed dunes that are retained by vegetation cover (Rizzini 1997, Lisboa et al 2011). The fixed dunes constitute a heterogeneous complex with species of Atlantic forest, Restinga and Cerrado and it has therefore a tropical, halophyte and xerophytic cosmopolitan flora. The dune ecosystems have important environmental benefits, preserving water resources, geological stability, biodiversity as well as improving the environment to human populations from their surroundings, softening temperatures, increasing humidity, fixing the sands, ensuring the permeability of the ground and acting in the hydrological dynamics of the water table (Damaso 2009). However, despite their biological relevance, the dunes of Rio Grande do Norte have experienced constant destruction due mainly to urbanization (Freire 1996) which may result in a significant loss of species.

The aim of this study was to evaluate the occurrence of AMF associated with fixing vegetation of coastal dunes from the Parque Ecológico Dunas de Genipabu, Rio Grande do Norte, Brazil, in order to understand the distribution of these organisms in coastal ecosystems.

\section{Materials \& Methods}

The samples were collected in the Parque Ecológico Dunas de Genipabu (35 $12^{\prime} 56^{\prime \prime} \mathrm{W}$ and $\left.05^{\circ} 40^{\prime} 40^{\prime \prime} \mathrm{S}\right)$, located in the eastern coastal part of the state of Rio Grande do Norte (RN), in the city of Extremoz (Fig. 1). The park area is surrounded by dunes whose vegetation consists of typical species of the Atlantic Forest, represented by herbaceous and shrub plant species and medium to large size (shrub-arboreal). It has tropical rainforest climate oscillating the temperature between $21{ }^{\circ} \mathrm{C}$ (minimum) and $30{ }^{\circ} \mathrm{C}$ (maximum), with an average of $26.1{ }^{\circ} \mathrm{C}$. The textural classification is sandy, with $\mathrm{pH}$ 5.6, organic carbon, $\mathrm{C} 16.6 \mathrm{mg} \mathrm{kg}^{-1}$ and $\mathrm{P}$ available, $3.0 \mathrm{mg} \mathrm{kg}^{-1}$.

The study period was from August / 2010 to February / 2012 on the dry and wet seasons consisting on a total of four occasions. A number of 48 samples comprising three sub-samples were taken from 0 to $20 \mathrm{~cm}$ depth in "zig zag", packed in plastic bags and brought to the laboratory. The host plants were collected and sent to the herbarium of the Universidade Federal do Rio Grande do Norte for identification. Glomerospores were obtained through the technique of wet sieving (Gerdemann \& Nicolson 1963) and centrifugation on sucrose (Jenkins 1964). Microscope slides were prepared in PVLG (polyvinyl alcohol and lactoglycerol) and PVLG + Reagent Melzer. The taxonomic evaluation followed taxonomic keys available in the literature (Schenck \& Pérez 1990, Goto 2009) and consultations on specialized sites (http://invam.wvu.edu/ and http://www.zor.zut.edu.pl/Glomeromycota/)

The data obtained were submitted to determine the number of AMF species per collection period, frequency of $\mathrm{AMF}$ species $(\mathrm{Fa}=\mathrm{Pa} / \mathrm{P} 100)$, Brillouin index $\left[\mathrm{HB}=\left(\ln \mathrm{N} !-\sum \ln \mathrm{n}_{\mathrm{i}} !\right) / \mathrm{N}\right]$ Simpson $\left(\mathrm{D}=1 / \Sigma \mathrm{p}_{\mathrm{i}}{ }^{2}\right)$, Shannon-Wiener $\left(\mathrm{H}^{\prime}=-\Sigma \mathrm{p}_{\mathrm{i}} \ln \mathrm{p}_{\mathrm{i}}\right)$, Margalef $(\mathrm{DMg}=(-1) / \ln \mathrm{N})$,

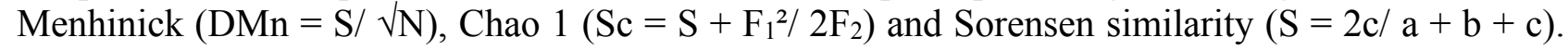
All analyzis were conducted using the software PAST version 1.81 (Hammer et al 2008). 


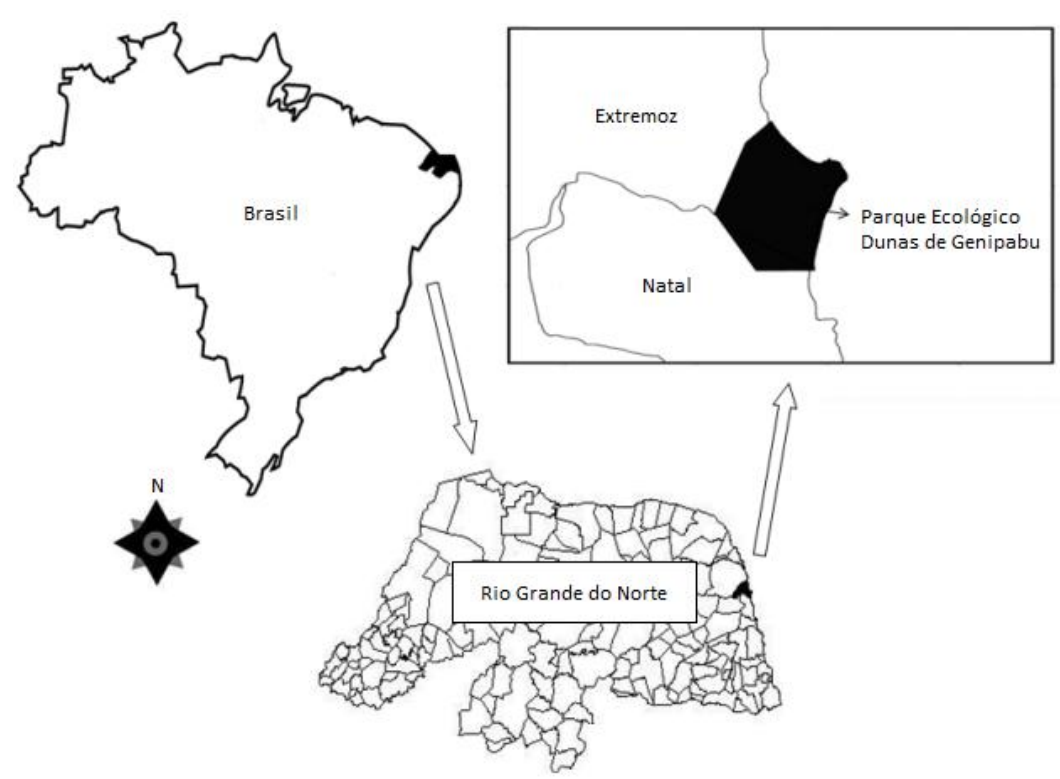

Fig. 1 - Parque Ecológico Dunas de Genipabu, Rio Grande do Norte, Brazil.

\section{Results}

A total of 46 AMF species were found, distributed in 10 families (Table 1). From the 15 families belonging to the Glomeromycota phylum (Goto et al 2012a, Oehl et al 2011a), 10 are represented in the AMF community of Parque Ecológico Dunas de Genipabu. Glomeraceae was the family with the highest number of species (12), followed by Acaulosporaceae (7), Dentiscutataceae (7), Gigasporaceae (5), Scutellosporaceae (4), Ambisporaceae (3), Racocetraceae (3), Intraornatosporaceae (2), Diversisporaceae (2) and Sacculosporaceae (1).

Table 1 AMF species occurring in the Parque Ecológico Dunas de Genipabu, RN, Brazil.

\begin{tabular}{|c|c|}
\hline Family & Species \\
\hline Acaulosporaceae & $\begin{array}{l}\text { Acaulospora cavernata Błaszk. } \\
\text { Acaulospora foveata Trappe \& Janos } \\
\text { Acaulospora lacunosa J.B. Morton } \\
\text { Acaulospora morrowiae Spain \& N.C. Schenck } \\
\text { Acaulopora scrobiculata Trappe } \\
\text { Acaulospora } \mathrm{sp} .1 \\
\text { Acaulospora } \mathrm{sp} .2\end{array}$ \\
\hline Ambisporaceae & $\begin{array}{l}\text { Ambispora appendicula (Spain, Sieverd. \& N.C. Schenck) } \\
\text { C. Walker } \\
\text { Ambispora gerdemannii (S.L. Rose, B.A. Daniels \& } \\
\text { Trappe) C. Walker, Vestberg \& A. Schüßler } \\
\text { Ambispora sp.1 }\end{array}$ \\
\hline Dentiscutataceae & $\begin{array}{l}\text { Dentiscutata biornata (Spain, Sieverd. \& S. Toro) } \\
\text { Sieverd., F.A. de Souza \& Oehl } \\
\text { Dentiscutata colliculosa B.T. Goto \& Oehl } \\
\text { Dentiscutata sp.1 } \\
\text { Dentiscutata sp. } \\
\text { Fuscutata heterogama Oehl, F.A. Souza, L.C. Maia \& } \\
\text { Sieverd. } \\
\text { Fuscutata rubra (Stürmer \& J.B. Morton) Oehl, F.A. de } \\
\text { Souza \& Sieverd. } \\
\text { Fuscutata } \text { sp. }\end{array}$ \\
\hline Diversisporaceae & $\begin{array}{l}\text { Corymbiglomus tortuosum (N.C. } \\
\text { Schenck et G.S. Sm.) Błaszk. \& Chwat }\end{array}$ \\
\hline
\end{tabular}




\begin{tabular}{|c|c|}
\hline Family & Species \\
\hline & $\begin{array}{l}\text { Redeckera fulva (Berk. \& Broome) C. Walker \& A. } \\
\text { Schüßler }\end{array}$ \\
\hline \multirow[t]{5}{*}{ Gigasporaceae } & Gigaspora albida N.C. Schenck \& G.S. Sm. \\
\hline & Gigaspora decipiens I.R. Hall \& L.K. Abbott \\
\hline & Gigaspora sp.1 \\
\hline & Gigaspora sp.2 \\
\hline & Gigaspora sp.3 \\
\hline \multirow[t]{14}{*}{ Glomeraceae } & Glomus glomerulatum Sieverd. \\
\hline & Glomus pachycaule (C.G. Wu \& Z.C. Chen) Sieverd. \& \\
\hline & Oehl \\
\hline & Glomus taiwanense (C.G. Wu \& Z.C. Chen) R.T. Almeida \\
\hline & \& N.C. Schenck \\
\hline & Glomus trufemii B.T. Goto, G. A. Silva \& Oehl \\
\hline & Glomus sp.1 \\
\hline & Glomus sp. 2 \\
\hline & Glomus sp.3 \\
\hline & Glomus sp.4 \\
\hline & Glomus sp.5 \\
\hline & Glomus sp.6 \\
\hline & Sclerocystis coremioides Berk. \& Broome \\
\hline & Sclerocystis sinuosa Gerd. \& B.K. Bakshi \\
\hline \multirow[t]{4}{*}{ Intraornatosporaceae } & Intraornatospora intraornata (B.T. Goto \& Oehl) B.T. \\
\hline & Goto, Oehl \& G.A. Silva \\
\hline & Paradentiscutata maritima B.T. Goto, D.K. Silva, Oehl \& \\
\hline & G.A. Silva \\
\hline \multirow[t]{6}{*}{ Racocetraceae } & Cetraspora gilmorei (Trappe \& Gerd.) Oehl, F.A. Souza \\
\hline & \& Sieverd. \\
\hline & Racocetra gregaria (N.C. Schenck \& T.H. Nicolson) \\
\hline & Oehl, F.A. Souza \& Sieverd. \\
\hline & Racocetra weresubiae (Koske \& C. Walker) Oehl, F.A. \\
\hline & Souza \& Sieverd. \\
\hline \multirow[t]{3}{*}{ Sacculosporaceae } & Sacculospora baltica (Błaszk., Madej \& Tadych) Oehl, \\
\hline & Palenz., I.C. Sánchez-Castro, B.T. Goto, G.A. Silva \& \\
\hline & Sieverd. \\
\hline \multirow[t]{5}{*}{ Scutellosporaceae } & Orbispora pernambucana (Oehl, D.K. Silva, N. Freitas \& \\
\hline & L.C. Maia) Oehl, G.A. Silva \& D.K. Silva \\
\hline & Scutellospora sp.1 \\
\hline & Scutellospora sp.2 \\
\hline & Scutellospora sp.3 \\
\hline
\end{tabular}

The evaluated plants correspond to the following species: Aristida setifolia Kunth, Acroceras zizanioides Kunth, Acroceras sp., Bouteloua sp., Cenchrus echinatus L., Digitaria sp., Digitaria bicornis (Lam.) Roem. \& Schult., Eragrostis maypurensis (Kunth) Steud., Gouinia virgata (J. Presl) Scribn., Streptostachys asperifolia Desv., Sporobolus virginicus (L.) Kunth, Sporobolus sp.1, Sporobolus sp.2, Paspalum sp1., Paspalum sp.2 (Poaceae), Cyperus ligularis L., Cyperus maritimus Poir., Cyperus meyenianus Kunth, Cyperus sp.1, Cyperus sp.2 (Cyperaceae), Eriocaulon sp. (Eriocaulaceae) and Hohenbergia sp. (Bromeliaceae). The number of AMF species obtained by plant species is shown in Table 2. Aristida setifolia was the plant species that showed the highest number of AMF species (17) while Cyperus meyenianus did not present AMF species in the rizosphere. The species with the highest frequency among the host plants evaluated were $A$. foveata, A. scrobiculata, A. appendicula, F. rubra, Gigaspora sp.1 and P. maritima (Table 3). 
Table 2 Number of AMF species evaluated by plant species.

\begin{tabular}{|c|c|}
\hline Plant species & Number of AMF species \\
\hline Acroceras sp. & 3 \\
\hline A. zizanioides & 4 \\
\hline A. setifolia & 17 \\
\hline Bouteloua sp. & 2 \\
\hline C. echinatus & 13 \\
\hline C. ligularis & 2 \\
\hline C. maritimus & 7 \\
\hline C. meyenianus & 0 \\
\hline Cyperus sp.1 & 1 \\
\hline D. bicornis & 4 \\
\hline Digitaria sp. & 3 \\
\hline E. maypurensis & 11 \\
\hline Eriocaulon sp. & 3 \\
\hline G. virgata & 15 \\
\hline Hohenbergia sp. & 11 \\
\hline Paspalum sp.2 & 4 \\
\hline Paspalum sp1. & 1 \\
\hline Sporobolus sp.1 & 13 \\
\hline Sporobolus sp.2 & 8 \\
\hline S. virginicus & 1 \\
\hline S. asperifolia & 1 \\
\hline
\end{tabular}

Table 3 Frequency of AMF species in the Parque Ecológico Dunas de Genipabu, RN, Brazil.

\begin{tabular}{llll}
\hline Species & Frequency & Species & Frequency \\
\hline A. appendicula & 16,67 & Gigaspora sp. 3 & 10,42 \\
A. cavernata & 8,33 & Glomus sp.1 & 8,33 \\
A. foveata & 16,66 & S. coremioides & 4,17 \\
A. gerdermanii & 4,17 & G. fulvum & 2,08 \\
A. lacunosa & 2,08 & Glomus sp.2 & 6,25 \\
A. morrowiae & 4,17 & G. glomerulatum & 2,08 \\
A. scrobiculata & 16,67 & G. pachyscaulis & 2,08 \\
Acaulospora sp. & 12,5 & S. sinuosa & 2,08 \\
Acaulospora sp. & 2,08 & G. tawanensis & 2,08 \\
Ambispora sp.1 & 2,08 & Glomus sp.3 & 4,17 \\
C. gilmorei & 2,08 & Glomus sp. 4 & 2,08 \\
C. tortuosum & 2,08 & Glomus sp.6 & 6,25 \\
D colliculosa & 2,08 & Glomus sp.5 & 10,42 \\
D. biornata & 4,17 & I. intraornata & 6,25 \\
Dentiscutata & 2,08 & Glomus sp.7 & 2,08 \\
Dentiscutata sp.1 & 4,17 & O. pernambucana & 2,08 \\
F. heterogama & 4,17 & P. maritima & 16,67 \\
F. rubra & 10,42 & R. gregaria & 14,58 \\
Fuscutata sp. & 2,08 & R. weresubiae & 2,08 \\
G. albida & 6,25 & S. baltica & 4,17 \\
G. decipiens & 8,33 & Scutellospora sp.1 & 4,17 \\
Gigaspora sp.1 & 25 & Scutellospora sp.2 & 4,17 \\
Gigaspora sp.2 & 6,25 & Scutellospora sp.3 & 4,17 \\
\hline & & & \\
\hline
\end{tabular}


Most of the AMF species found in the Parque Ecológico Dunas de Genipabu also had records of occurrence on coastal dunes in Brazil and tropical and temperate regions worldwide (Table 4). The dry season (August /2010, August /2011) was associated with a higher number of species and diversity indexes (Table 5). There was a high similarity to the dunes of Santa Catarina, Brazil, followed by dunes of Paraíba, Brazil and Bornhom, Denmark (Table 6).

Table 4 Occurrence of the species found in the Parque Ecológico Dunas de Genipabu, RN, Brazil in other coastal areas worldwide.

\begin{tabular}{|c|c|c|}
\hline Local & Species & Reference \\
\hline $\begin{array}{l}\text { Bahia, Paraíba and Rio Grande do Norte } \\
\text { (Brazil) }\end{array}$ & I. intraornata, P. maritima, R. fulva & $\begin{array}{l}\text { Santos et al 1995, Goto et al } \\
2012 \mathrm{a}\end{array}$ \\
\hline Bermuda & G. albida & Schenck \& Smith 1982 \\
\hline California (USA) & F. heterogama & Rose 1988 \\
\hline $\begin{array}{l}\text { Florida, Maryland, New Jersey, } \\
\text { Virginia, North Carolina (USA) }\end{array}$ & $\begin{array}{l}\text { A. morrowiae, A. scrobiculata, } R \text {. } \\
\text { weresubiae }\end{array}$ & $\begin{array}{l}\text { Koske \& Walker 1986, } \\
\text { Sylvia } 1986\end{array}$ \\
\hline $\begin{array}{l}\text { Gdansk, Szczecin, Stowiński National } \\
\text { Park (Poland) }\end{array}$ & A. cavernata, A. lacunosa & 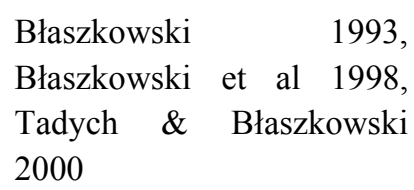 \\
\hline $\begin{array}{l}\text { Haringvlietdam and } \quad \text { Ouddorp } \\
\text { (Netherlands) }\end{array}$ & R. gregaria & Kowalchuk 2002 \\
\hline Hasaki (Japan) & C. tortuosum, R. gregaria & Jun-Ichi et al 1994 \\
\hline Hawaii (USA) & A. scrobiculata, S. sinuosa & $\begin{array}{l}\text { Koske } 1988, \text { Koske \& } \\
\text { Gemma } 1996\end{array}$ \\
\hline Hel Peninsula (Poland) & A. cavernata, A. lacunosa & $\begin{array}{l}\text { Błaszkowski 1989, 1992, } \\
1994\end{array}$ \\
\hline India & G. albida, G. pachyscaulis & Thangaswamy \& Kim 2004 \\
\hline Island Bornholm (Denmark) & A. lacunosa & $\begin{array}{l}\text { Błaszkowski } \quad \& \\
\text { Czerniawska } 2011\end{array}$ \\
\hline Karnataka (India) & $\begin{array}{l}\text { A. scrobiculata, G. albida, G. pachyscaulis, } \\
\text { G. tortuosum, R. gregaria }\end{array}$ & $\begin{array}{l}\text { Kulkarni et al 1997, Beena } \\
\text { et al 2001, Kamble et al } \\
2012 \text { c, }\end{array}$ \\
\hline Kaup (India) & $\begin{array}{l}\text { A. scrobiculata, D. biornata, G. albida, } S \text {. } \\
\text { sinuosa, } R \text {. weresubiae }\end{array}$ & D’Cunha \& Sridhar 2009 \\
\hline Kibutz Shefayim to Tel-Aviv (Israel) & S. sinuosa & $\begin{array}{l}\text { Błaszkowski } \\
\text { Czerniawska } 2006\end{array}$ \\
\hline Maharashtra (India) & A. scrobiculata, G. pachyscaulis, S. sinuosa & Kamble et al 2012a, b \\
\hline $\begin{array}{l}\text { Massachussets, New Jersey, Rhode, } \\
\text { South Carolina and Virginia (USA) }\end{array}$ & $\begin{array}{l}\text { A. lacunosa, A. scrobiculata, } F \text {. heterogama, } \\
\text { R. gregaria }\end{array}$ & $\begin{array}{l}\text { Koske \& Walker 1985, } \\
\text { Gemma et al 1989, Koske } \\
\text { \& Gemma } 1996\end{array}$ \\
\hline New Jersey to Virginia (USA) & $\begin{array}{l}\text { A. scrobiculata, G. albida, C. tortuosum, } R \text {. } \\
\text { gregaria, } R \text {. weresubiae }\end{array}$ & Koske 1987 \\
\hline New Zealand & S. coremioides & Hall 1977 \\
\hline Paraíba (Brazil) & $\begin{array}{l}\text { A. foveata, } A . \text { morrowiae, } A \text {. scrobiculata, } A \text {. } \\
\text { appendicula, D. biornata, D. colliculosa, } F \text {. } \\
\text { heterogama, G. decipiens, , G. } \\
\text { glomerulatum, I. intraornata, } O \text {. } \\
\text { pernambucana, S. sinuosa, G. taiwanensis, } \\
\text { C. tortuosum, P. maritima, R. gregaria, } S . \\
\text { coremioides }\end{array}$ & $\begin{array}{l}\text { Goto et al 2009, } 2010 \text {, } \\
\text { Oliveira et al } 2009, \text { Oehl et } \\
\text { al } 2011 \text { b, Souza et al } 2011 \text {, } \\
\text { Silva et al } 2012\end{array}$ \\
\hline Rhode Island (USA) & A. scrobiculata & $\begin{array}{l}\text { Koske 1981, Friese \& } \\
\text { Koske } 1991\end{array}$ \\
\hline
\end{tabular}




\begin{tabular}{|c|c|c|}
\hline Local & Species & Reference \\
\hline Rio Grande do Norte (Brazil) & G. trufemmii & Goto et al $2012 b$ \\
\hline Santa Catarina (Brazil) & $\begin{array}{l}\text { A. apendicula, A. cavernata, A. foveata, } A . \\
\text { gerdemani, A. lacunosa, A. morrowiae, } A . \\
\text { scrobiculata, G. albida, G. decipiens, } R . \\
\text { gregaria, } R . \text { weresubiae, S. sinuosa }\end{array}$ & $\begin{array}{l}\text { Cordoba et al 2001, } \\
\text { Cordazzo \& Stürmer 2007, } \\
\text { Stürmer et al } 2013\end{array}$ \\
\hline São Paulo (Brazil) & $\begin{array}{l}\text { A. appendicula, A. foveata, A. lacunosa, } A . \\
\text { scrobiculata, C. gilmorei, G. albida, G. } \\
\text { decipiens, R. gregaria, S. coremioides, S. } \\
\text { sinuosa }\end{array}$ & $\begin{array}{l}\text { Trufem et al 1989, } 1994, \\
\text { Trufem 1990, 1995, }\end{array}$ \\
\hline Tuscany (Italy) & R. gregaria & Giovanetti 1985 \\
\hline $\begin{array}{l}\text { Uchila, Someshwara, Bengre, Surathkal, } \\
\text { Malpe, Uppala, Thalapady, Ullal, } \\
\text { Panambur and Kaup (India) }\end{array}$ & G. albida, C. tortuosum & Beena et al 2000 \\
\hline
\end{tabular}

Table 5 Species number, Brillouin index, Simpson, Shannon-Wiener, Margalef, Menhinick and Chao 1.

\begin{tabular}{lcccc}
\hline Rates & $\begin{array}{c}\text { August/ 2010 } \\
\text { Dry season }\end{array}$ & $\begin{array}{c}\text { March/ 2011 } \\
\text { Wet season }\end{array}$ & $\begin{array}{c}\text { August/ 2011 } \\
\text { Dry season }\end{array}$ & $\begin{array}{c}\text { February/ 2012 } \\
\text { Wet season }\end{array}$ \\
\hline Number of Species (S) & 27 & 16 & 27 & 15 \\
Simpson (D) & 0,95 & 0,92 & 0,95 & 0,92 \\
Shannon (H) & 3,19 & 2,67 & 3,16 & 2,60 \\
Brillouin & 2,61 & 2,15 & 2,52 & 2,02 \\
Menhinick & 3,71 & 2,70 & 4,02 & 2,89 \\
Margalef & 6,55 & 4,22 & 6,83 & 4,25 \\
Chao-1 & 31,50 & 23,50 & 44,14 & 19,20 \\
\hline
\end{tabular}

Table 6 Sorensen similarity between Parque Ecológico Dunas de Genipabu, RN, Brazil and other coastal areas worldwide.

\begin{tabular}{ll}
\hline Location & Similarity \\
\hline Kibutz Shefayim to Tel-Aviv (Israel) & 0,03 \\
Les Salines, El Prat, Viladecans (Spain) & 0 \\
Natural Reserve of São Jacinto and Comporta (Portugal) & 0 \\
Bahia (Brazil) & 0 \\
California (USA) & 0 \\
Florida (USA) & 0,17 \\
Hasaki (Japan) & 0,13 \\
Hawaii (USA) & 0,12 \\
Hel Peninsula (Poland) & 0.07 \\
Island Bornhom (Denmark) & 0,32 \\
Karnataka (India) & 0,14 \\
Kaup (India) & 0,15 \\
Massachusetts (USA) & 0,07 \\
Paraíba (Brazil) & 0,32 \\
Rhode Island (USA) & 0 \\
Santa Catarina (Brazil) & 0,38 \\
São Paulo (Brazil) & 0,20 \\
Szczecin (Poland) & 0,06 \\
Tuscany (Italy) & 0 \\
\hline
\end{tabular}




\section{Discussion}

Acaulospora, Gigaspora, Glomus and Scutellospora are the most common AMF genera in coastal areas worldwide (Maun 2009), a pattern verified in this study, in wich the species most frequent were belonging to the genera Acaulospora and Gigaspora. Acaulospora scrobiculata is the most common species on coastal areas around the world and also showed a high frequency in the Parque Ecológico Dunas de Genipabu.

The high representativeness obtained for the family Glomeraceae is in accordance with the results obtained by Trufem (1990, 1995) and Souza et al (2011) during studies conducted in the sandy coast of Ilha do Cardoso, São Paulo and dunes from Mataraca, Paraíba in which Glomeraceae also exhibited higher representation. Nevertheless, we highlight that Glomeraceae is the most diverse and numerous family in the Glomeromycota phylum (Lista Global das Espécies do Filo Glomeromycota 2015), presenting occurrence in different Brazilian ecosystems. Therefore, the high variability within this clade in terms of species diversity and ecological adaptations may explain its high incidence in dune areas.

The plants show different degrees of mycotrophic status, though a substantial number of species is potentially mycotrophic and only a few families do not form mycorrhizae (Cardoso et al 2010). According to Cardoso \& Kuyper (2006), however, each of these families have few representatives who may be colonized by mycorrhizal fungi, such as the family Cyperaceae (Muthukumar et al 2004), an aspect which can be supported by the absence of glomerospores in the rhizosphere of $C$. meyenianus in contrast to the presence of glomerospores in the rhizosphere of $C$. maritimus.

Physical factors such as temperature and humidity have directly influence on the presymbiotic phase (Maia et al 2010). A higher number of AMF species (27) was detected in the dry season (Table 4), which recorded higher temperature and lower rainfall $\left(28^{\circ} \mathrm{C}, 31^{\circ} \mathrm{C}\right.$ and $106 \mathrm{~mm}$ for August/ 2010 and August/ 2011 respectively). The pattern obtained was similar to that observed by Souza et al (2011) in the dunes impacted by mining in Mataraca, Paraíba, Brazil, where there was a higher number of species associated with the dry season.

Silva et al 2012, in reforested dunes from Mataraca, Paraíba, Brazil, obtained a value equivalent to 2.79 to the diversity of Shannon-Wiener, pattern close to the obtained at the Parque Ecológico Dunas de Genipabu during the rainy seasons (2.67 and 2.60 in March/ 2011 and February/ 2012 respectively). A similar result was obtained for the diversity of Simpson recorded at 0.93 to the dunes of Mataraca, 0.92 during the dry season and 0.95 during the rainy season to the Parque Ecológico Dunas de Genipabu.

Stürmer et al (2010) reported 65 species in a review about the occurrence of AMF in coastal dunes, a number that represents $24 \%$ of the species described from the Glomeromycota phylum (Lista Global das Espécies do Filo Glomeromycota, 2015) and this value shows the importance of these habitats to the discovery of new AMF species. Scutellospora hawaiiensis Koske \& Gemma, a species reported for such areas, was recorded exclusively in coastal dune area (Gemma \& Koske 1995). Among the 153 species that occur in Brazil six were originally described from material originated from coastal dunes (Acaulospora herrerae Furrazola, B.T. Goto, G.A. Silva, Sieverd. \& Oehl, Acaulospora ignota Błaszk., Góralska, Chwat \& Goto, G. trufemii, P. maritima, Racocetra tropicana Oehl, B.T. Goto \& G.A. Silva and Rhizoglomus natalense (Błaszk., Chwat \& B.T. Goto) Sieverd., G.A. Silva \& Oehl) of which five species were discovered on the coastal dunes in Rio Grande do Norte (A. herrerae, A. ignota, G. trufemii, P. maritima and $R$. natalense) (Goto et al 2011, 2012a, b, Furrazola et al 2013, Błaszkowski et al 2014, 2015). These discoveries show that the dunes of Rio Grande do Norte are taxonomically promising areas.

The number of species obtained in the present study exceeds the average obtained for studies about AMF diversity (21) in other Brazilian coastal areas (Trufem et al 1989, 1994 Trufem 1990, 1995, Stürmer \& Bellei 1994, Santos et al 1995, Cordoba et al 2001, Cordazzo \& Stürmer 2007, Oliveira et al 2009, Souza et al 2011, Silva et al 2012, Stürmer et al 2013). Furthermore, the high number of species recorded in this study shows that coastal dunes poorly studied or unexplored in tropical areas are potential reservoirs of AMF species. Just as it happens in Campos 
Rupestres, where only two diversity studies totalized 69 AMF species, Brazilian dunes have a significant species number front to other ecosystems, in contrast to the low number of inventories developed and the wide availability of areas to be explored in this aspect (Souza et al 2010, Carvalho et al 2012, Coutinho et al 2015).

The data indicate that dune areas are important reservoirs of AMF species by the high number of species associated with coastal vegetation of the Parque Ecológico Dunas de Genipabu.

\section{Acknowledgements}

We would like to thank the Conselho Nacional de Desenvolvimento Científico e Tecnológico $(\mathrm{CNPq})$ for the financial support granted to Khadija Jobim. We also thank Dr. Jomar Gomes Jardim, professor at the Universidade Federal do Rio Grande do Norte for the identification of the studied plants. We thank FAPERN, SISBIOTA, INCT Flora e Fungos and CNPq for the financial support from the Universal edict and the productivity scholarship granted to Bruno Tomio Goto.

\section{Reference}

Allen EB, Cunninghamm, GL. 1983 - Effects of vesicular-arbuscular mycorrhizae on Distichlisspicata under three salinities levels. New Phytologist. 95,125-132.

Barbour MC. 1992 - Life at the leading edge: the beach plant syndrome. In: Coastal plant communities of Latin America (ed Seeliger, U.) Academic Press, San Diego, 291-306.

Beena K.R, Arun AB, Raviraja NS, Sridhar KR. 2000 - Diversity of arbuscular mycorrhizal fungi on the coastal sand dunes of west coast of India. Current Science 79, 1459-1466.

Beena KR, Arun AB, Raviraja NS, Sridhar KR. 2001 - Association of arbuscular mycorrhizal fungi with plants of coastal sand dunes of west coast of India. Tropical Ecology 42, 213-222.

Berch SM, Trappe JM. 1985 - A new species of Endogonaceae, Glomus hoi. Mycologia 77, 654657.

Błaszkowski J. 1989 - Acaulospora cavernata (Endogonales), a new species from Poland with pitted spores. Cryptogamic Botany 1, 204-207.

Błaszkowski J. 1992 - Scutellospora armeniaca, a new species in Glomales (Zygomycetes) from Poland. Mycologia 84, 939-944.

Błaszkowski J. 1993 - The occurrence of arbuscular fungi and mycorrhizae (Glomales) in plant communities of maritime dunes and shores of Poland. Bulletin of the Polish Academy of Sciences - Biological Sciences 41, 377-392.

Błaszkowski J. 1994 - Arbuscular fungi and mycorrhizae (Glomales) of The Hell Peninsula. Mycorrhiza 5, 71-88.

Błaszkowski J, Tadych M, Madej T. 1998 - Endogone maritima, a new species in the Endogonales from Poland. Mycological Research 102, 1096-1100.

Błaszkowski J, Blanke V, Renker C, Buscot F. 2004 - Glomus aurantium and Glomus xanthium, new species in Glomeromycota. Mycotaxon 90, 447-467.

Błaszkowski J, Czerniawska B. 2006 -The ocurrence of arbuscular mycorrhizal fungi of the phylum Glomeromycota in Israeil soils. Acta Societatis Botanicorum Poloniae 65, 339-350.

Błaszkowski J, Czerniawska B. 2008 - Glomus irregulare, a new arbuscular mycorrhizal fungus in the Glomeromycota. Mycotaxon 106, 247-267.

Błaszkowski J, Czerniawska B. 2011 - Arbuscular mycorrhizal fungi (Glomeromycota) associated with roots of Ammophila arenaria growing in maritime dunes of Bornholm (Denmark). Acta Societatis Botanicorum Poloniae 80, 63-76.

Błaszkowski J, Chwat G, Goto BT. 2014 - Rhizophagus natalensis, a new species in the Glomeromycota. Mycotaxon 129, 97-108.

Błaszkowski J, Chwat G, Góralska A. 2015 - Acaulospora ignota and Claroideoglomus hanlinii, two new species of arbuscular mycorrhizal fungi (Glomeromycota) from Brazil and Cuba. Mycological Progress 14-18. 
Cardoso IM, Kuyper TW. 2006 - Mycorrhiza and tropical soil fertility. Agriculture, ecosystem \& Environment 116, 72-84.

Cardoso EJBN, Cardoso IM, Nogueira MA, Barreta CRDM, Paula A. M. 2010 - Micorrizas arbusculares na aquisição de nutrientes pelas plantas. In: Micorrizas: 30 anos de pesquisas no Brasil (eds: Siqueira, JO, Souza FA, Cardoso EJBN, Tsai SM). Editora UFLA, Lavras, $153-214$.

Carvalho F, Souza FA, Carrenho R, Souza FMM, Jesus EC, Fernandes GW. 2012 - The mosaic of habitats in the high-altitude Brazilian rupestrian fields is a hotspot for arbuscular mycorrhizal fungi. Applied Soil Ecology 52, 9 - 19.

Cordazzo CV, Stürmer SL. 2007 - Ocorrência de fungos micorrízicos arbusculares em Panicum racemosum (P. Beauv.) Spreng (Poaceae) em dunas costeiras do extremo sul do Brasil. Atlântica, Rio Grande 29, 65-68.

Cordoba AS, Mendonça MM, Stürmer SL, Rygiewicz PT. 2001 - Diversity of arbuscular mycorrhizal fungi along a sand dune stabilization gradient: A case study at Praia da Joaquina, Ilha de Santa Catarina, South Brazil. Mycoscience 42, 379-387.

Coutinho ES, Fernandes GW, Berbara RLL, Valério HM, Goto BT. 2015. Variation of arbuscular mycorrhizal fungal communities along an altitudinal gradient in rupestrian fields in Brazil. Mycorrhiza 25, 627-638.

Damaso PP. 2009 - Vegetação dunar: caracterização estrutural de dunas do município de Natal RN como subsídio para implantação de técnicas de reflorestamento, recuperação e conservação do ecossistema. Universidade Federal do Rio Grande do Norte, 79 p.

D'Cunha M, Sridhar K. 2009 - Seasonal periodicity of arbuscular mycorrhizal fungi in wild legume Canavalia maritima of the coastal sand dunes. Mycorrhiza News 21, 7-12.

Freire EMX. 1996 - Estudo ecológico e zoogeográfico sobre a fauna de lagartos (Sauria) das dunas de Natal, Rio Grande do Norte e da Restinga de Ponta de Campina, Cabedelo, Paraíba, Brasil. Revista Brasileira de Zoologia 13, 903-921.

Friese CS, Koske RE. 1991 - The spatial dispersion of spores of vesicular-arbuscular mycorrhizal fungi in a sand dune: microscale patterns associated with the root architecture of American beachgrass. Mycological Research 95, 952-957.

Furrazola E, Goto BT, Silva GA, Arias YT, Morais T, Lima CEP, Ferreira ACA, Maia LC, Sieverding E, Oehl F. 2013 - Acaulospora herrerae, a new pitted species in the Glomeromycetes from Cuba and Brazil. Nova Hedwigia 97, 401-413.

Gemma JN, Koske RE, Carreiro M. 1989 - Seasonal dynamics of selected species of V-A mycorrhizal fungi in a sand dune. Mycological Research 92, 317-321.

Gemma JN, Koske RE. 1995 - Scutellospora hawaiiensis: a new species of arbuscular mycorrhizal fungus from Hawaii. Mycologia 87, 678-683.

Gerdemann JW, Nicolson TH. 1963 - Spores of mycorrhizal Endogone species extracted from soil by wet-sieving and decanting. Transactions of the British Mycological Society 46, 235-244.

Gerdemann JW, Trappe JM. 1974 - The Endogonaceae of the Pacific Northwest. Micologie Memoir 5, 1-76.

Gianinazzi S, Gianinazzi-Peason V. 1986 - Progress and headaches in endomycorrhiza biotechnology. Symbiosis 2, 139-149.

Giovannetti M. 1985 - Seasonal variations of vesicular-arbuscular mycorrhizas and Endogonaceous spores in a maritime sand dune. Transactions of the British Mycological Society 84, 679-684.

Goto BT. 2009 - Taxonomia de Glomeromycota: revisão morfológica, chaves dicotômicas e descrição de novos táxons. Universidade Federal de Pernambuco, 358 p.

Goto BT, Maia LC, Silva GA, Oehl F. 2009 - Racocetra intraornata, a new species in the Glomeromycetes with a unique spore wall structure. Mycotaxon 109, 483-491.

Goto BT, Maia LC, Silva GA, Maia LC, Oehl F. 2010 - Dentiscutata colliculosa, a new species in the Glomeromycetes from Northeastern Brazil with colliculate spore ornamentation. Nova Hedwigia 90, 383-393. 
Goto BT, Silva GA, Maia LC, Souza RG, Coyne D, Tchabi A, Lawouin FH, Oehl F. 2011 Racocetra tropicana, a new species in the Glomeromycetes from tropical areas. 2011. Nova Hedwigia 92, 69-82.

Goto BT, Silva GA, Assis DMA, Silva DKA, Souza RG, Ferreira ACA, Jobim K, Mello CMA, Vieira HEE, Maia LC, Oehl F. 2012a - Intraornatosporaceae (Gigasporales), a new family with two new genera and two new species. Mycotaxon 119, 117-132.

Goto BT, Jardim JG, Silva GA, Furrazola E, Torres-Arias Y, Oehl F. 2012b - Glomus trufemii (Glomeromycetes), a new sporocarpic species from Brazilian sand dunes. Mycotaxon 120, $1-9$.

Hall IR. 1977 - Species and mycorrhizal infections of New Zeland Endogonaceae. Transactions of the British Mycological Society 68, 341-256.

Hammer Ø, Harper DAT, Ryan PD. 2008 - PAST - PAlaeontological STatistics, version 1.81, Manual. http://folk.uio.no/ohammer/past.

Janos DP. 1980 - Mycorrhizae influence tropical sucession. Biotropica 12, 56-96.

Jenkins WR. 1964 - A rapid centrifugal - flotation technique for separating nematodes from soil. Plant Disease 48, 692.

Jun-ichi PA, Masuhara G, Katsuya K. 1994 - Vesicular arbuscular mycorrhizal fungi in coastal dune plant communities. I. Spore formation of Glomus spp. predominates under a patch of Elymus mollis. Mycoscience 35, 233-238.

Kamble VR, Agre DG, Dixit GB. 2012a - Incidence of Arbuscular Mycorrhizal Fungi in Indian Squill: Drimia indica from Coastal Sand Dunes of Konkan, India. IOSR Journal of Pharmacy and Biological Sciences 4, 31-36.

Kamble VR, Sayed BK, Qureshi N. 2012b - Screening of CSDPs for AM Fungal Association from Arnala and Kalamb Beach Maharashtra. IOSR Journal of Pharmacy and Biological Sciences 4, 44-47.

Kamble VR, Thangadurai D, Rahate HL, Agre DG. 2012c - Status of AM Fungi in Some Medicinal Plants from Panambur Beach Mangalore India. IOSR Journal of Pharmacy and Biological Sciences 4, 1-4.

Koske RE. 1981 - A preliminary study of interactions between species of vesicular-arbuscular fungi in a sand dune. Transactions of the British Mycological Society 76, 411-416.

Koske RE. 1987 - Distribution of VA mycorrhizal fungi along a latitudinal temperature gradient. Mycologia 79, 56-68.

Koske RE. 1988 - Vesicular-arbuscular mycorrhizae of some hawaiian dune plants. Pacific Science 42, 3-4.

Koske RE, Walker C. 1985 - Species of Gigaspora (Endogonaceae) with roughened outer walls. Mycologia 77, 702-720.

Koske RE, Walker C. 1986 - Species of Scutellospora (Endogonaceae) with smooth-walled spores from maritime sand dunes: two news species and a redescription of the spores of Scutellospora pellucida and Scutellospora calospora. Mycotaxon 27, 219-235.

Koske RE, Gemma JN. 1996 - Arbuscular mycorrhizal fungi in hawaiian sand dunes: island of Kaua'i. Pacific Science 50, 36-45.

Kowalchuk GA, Souza FA, Van Veen JA. 2002 - Community analysis of arbuscular mycorrhizal fungi associated with Ammophila arenaria in Dutch coastal sand dunes. Molecular Ecology $11,571-581$.

Kulkarni SS, Raviraja NS, Sridhar KR. 1997 - Arbuscular mycorrhizal fungi of tropical sand dunes of west coast of India. Journal of Coastal Research 13, 931-936.

Levy Y, Dodd J, Krikun, J. 1983 - Effect of irrigation, water salinity and rootstock on the vertical distribution of vesicular-arbuscular mycorrhizal in citrus roots. New Phytologist 95, 397403.

Lisboa CMCA, Campos UM, Souza SKS. 2011 - Mapeamento e caracterização dos remanescentes de dunas do município de Natal - RN, Brasil. REVSBAU 6, 64-83. 
Lista Global das Espécies do Filo Glomeromycota. 2015 http://glomeromycota.wix.com/lbmicorrizas. (acessed 04 feb 2016).

Maia LC, Silva FSB, Goto BT. 2010 - Estrutura, ultraestrutura e germinação de glomerosporos. In Micorrizas: 30 anos de pesquisas no Brasil (eds Siqueira JO, Souza FA, Cardoso EJBN, Tsai SM) Editora UFLA, Lavras, $76-118$.

Maun MA. 2009 - The biology of coastal sand dunes. Oxford University Press, New York.

McGee PA, Trappe JM. 2002 - The Australian Zygomycetous mycorrhizal fungi.II. further australian sporocarpic Glomaceae. Australian Systematic Botany 15, 115-124.

Muthukumar T, Udaiyan K, Shanmughavel P. 2004 - Mycorrhiza in sedges - an overview. Mycorrhiza 14, 65-77.

Oehl F, Sieverding E, Palenzuela J, Ineichen K, Silva GA. $2011 \mathrm{a}$ - Advances in Glomeromycota taxonomy and classification. IMA Fungus 2, 191-199.

Oehl F, Silva DKA, Maia LC, Sousa NMF,Vieira HEE, Silva GA. 2011b - Orbispora gen. nov., ancestral in the Scutellosporaceae (Glomeromycetes). Mycotaxon 116, 161-169.

Oehl F, Sánchez-Castro I, Palenzuela J, Silva GA. 2014. Palaeospora spainii, a new arbuscular mycorrhizal fungus from Swiss agricultural soils. Nova Hedwigia 101, 1-2.

Oliveira JRG, Souza RG, Silva FSB, Mendes ASM, Yano-Melo AM. 2009 - O papel da comunidade de fungos micorrízicos arbusculares (FMA) autóctones no desenvolvimento de espécies vegetais nativas em área de dunas de restinga revegetadas no litoral do Estado da Paraíba. Revista Brasileira de Botânica. 32, 663-670.

Ranwell D. 1959 - Newborough Warren Anglesey. I. the dune system and dune slack habitat. Journal of Ecology 47, 571-601.

Reeves FB, Wagner D, Moorman T, Kiel J. 1979. The role of endomycorrhizae in revegetation practices in the semi-arid West. I. A comparison of incidence of mycorrhizae in severely distuberd vs. natural environments. American Journal of Botany 66, 6-13.

Rizzini CT. 1997 - Tratado de Fitogeografia do Brasil: aspectos ecológicos, sociológicos e florísticos. São Paulo: Âmbito Cultural, 747 p.

Rose S. 1988 - Above and belowground community development in a marine sand dune ecosystem. Plant and Soil 109, 215-226.

Santos OM, Oliveira NC, Novais RF. 1995 - Observações preliminares sobre fungos micorrízicos vesículo-arbusculares em plantas crescendo em dunas na Bahia. Revista Ceres 42, 191202.

Schenck NC, Pérez Y. 1990 - Manual for the identification of VA mycorrhizal fungi. Gainesville: Synergistic Publications, $241 \mathrm{p}$.

Schenck NC, Smith GS. 1982 - Additional new and unreported species of mycorrhizal fungi (Endogonaceae) from Florida. Mycologia 74, 77-92.

Silva DKA, Pereira CMR, Souza RG, Silva GA, Oehl F, Maia LC. 2012 - Diversity of arbuscular mycorrhizal fungi in resting and dunes areas in Brazilian Northeast. Biodiversity and Conservation 21, 2361-2373.

Souza FA, Silva ICL, Berbara RLL. 2007 - Fungos Micorrízicos Arbusculares: muito mais diversos do que se imaginava. Biodiversidade 14, 483-536.

Souza FA, Stürmer SL, Carrenho R, Trufem SFB 2010 - Classificação e taxonomia de fungos micorrízicos arbusculares e sua diversidade e ocorrência no Brasil. In: Micorrizas: 30 anos de pesquisas no Brasil (eds: Siqueira, JO, Souza FA, Cardoso EJBN, Tsai SM). Editora UFLA, Lavras, 15-73.

Souza RG, Silva DKA, Mello CMA, Goto BT, Silva FSB, Sampaio EVSB, Maia LC. 2011 Arbuscular mycorrhizal fungi in revegetated mined dunes. Land Degradation \& Development 24, 147-155.

Smith SE, Read D. 2008 - Mycorrhizal Symbiosis. $3^{\text {a }}$ ed. Academic Press, San Diego, 605p.

Stürmer SL, Bellei MM. 1994 - Composition and seasonal variation of spore populations of arbuscular mycorrhizal fungi in dune soils on the island of Santa Catarina, Brazil. Canadian Journal of Botany 72, 359-363. 
Stürmer SL, Melloni R, Caproni AL. 2010 - Micorrizas Arbusculares em dunas marítimas e em áreas de mineração. In: Micorrizas: 30 anos de pesquisas no Brasil (eds: Siqueira, JO, Souza FA, Cardoso EJBN, Tsai SM). Editora UFLA, Lavras, 341-356.

Stürmer SL, Stürmer R, Pasqualini D. 2013 - Taxonomic Diversity and community structure of arbuscular mycorrhizal fungi (Phylum Glomeromycota) in three maritime sand dunes in Santa Catarina State, South Brazil. Fungal Ecology 6, 27-36.

Sylvia DM. 1986 - Spatial and temporal distribution of vesicular-arbuscular mycorrhizal fungi associated with Uniola paniculata in Florida foredunes. Mycologia 78, 728-734.

Tadych M, Błaszkowski J. 2000 - Arbuscular fungi and mycorrhizae (Glomales) of the Słowiński National Park, Poland. Mycotaxon 2, 463-482.

Thangaswamy S, Kim H. 2004 - Ecology of vesicular-arbuscular mycorrhizal (VAM) fungi in coastal areas of India. Journal of Applied Biological Chemistry 47, 71-76.

Trufem SFB. 1990 - Aspectos ecológicos de fungos micorrízicos vesículo-arbusculares da mata tropical úmida da Ilha do Cardoso, SP, Brasil. Acta Botanica Brasilica 4, 31-45.

Trufem SFB. 1995 - Fungos Micorrízicos Arbusculares em rizosferas de plantas de duna do Parque Estadual da Ilha do Cardoso, SP, Brasil. Revista Brasileira de Botânica 18, 51-60.

Trufem SFB, Otomo HS, Malatinszky SMM. 1989 - Fungos micorrízicos vesículos arbusculares em rizosferas de plantas em dunas do Parque Estadual da Ilha do Cardoso, São Paulo, Brasil. Acta Botanica Brasilica 3, 141-152.

Trufem SFB, Malatinszky SMM, Otomo HS. 1994 - Fungos micorrízicos arbusculares em rizosferas de plantas do litoral arenoso do Parque Estadual da Ilha do Cardoso, SP, Brasil. Acta Botanica Brasilica 8, 219-229.

Wilson JB, Sykes MT. 1999 - Is zonation on coastal sand dunes determined primarily by sand burial or by salt spray? A test in New Zealand dunes. Ecology Letters 2, 233-236. 